\title{
Intellectualism and Interesting Facts on Baboons (Papio anubis Les.; Family: Cercopithecidae) (the olive baboons) in Yankari Game Reserve, Bauchi, Nigeria
}

\author{
Ukwubile Cletus Anes \\ Department of Science Laboratory Technology, Biology Unit, \\ School of Science and Technology, Federal Polytechnic Bali, Nigeria.
}

\begin{abstract}
Baboons are the type of monkey that are found in African forests and the Arabians. There are five species of baboons worldwide which are distributed in different habitats such as tropical rainforests, savannas, open woodlands and semi-arid areas. A close observation made on baboons at the Yankari Game Reserve(YGR), showed that they feed on various foods which are the reason they are known as pests as well as they are scavengers on elephant's dung. Apart from poaching activity by humans, baboons at YGR are also threatened by loss of habitat due to regular predatory activity by a lion (Pathera leo) in the reserve on the baboons. Out of the five species, only one species (Papio anubis) are found in the large population at the Yankari Game Reserve. This increase in the population of the olive baboons at the YGR has become a source of concern to tourists and researchers who visit the reserve. Due to frequent visits by people to the reserve, the baboons has developed a high level of intellectualism as well as tricks to overcome the dominance by humans encroaching their habitat. Some of these behaviours are groupings, pretence, and acrobatics. The study showed that baboons at YGR developed these level of intellectualism to overcome threats from humans and some carnivores such as lions, to survive during food shortage in the main forests, and to minimize inter-specific competition in the reserve. It is therefore, advised that the increased in population of the olive baboons at YGR should be checked to forestall any ugly incident to visitors to the reserve.
\end{abstract}

Keywords: Baboons, Papio anubis, Yankari Game Reserve, Intellectualism.

\section{INTRODUCTION}

Baboons are medium to large sized species of old world monkey that are found in a variety of habitats throughout Africa and in some parts of Arabia[1]. There are five different species of baboon which includes: olive baboon, the Guinea baboon, the Chacma baboon, the yellow Baboon and the Himalayas baboon which differs mostly from others species with its bright red face and cliff-dwelling lifestyle, the other four species are collectively known as Savannah baboons. At Yankari Game Reserve in Bauchi State Nigeria, only one species is dominant - the olive baboons (Papio anubis ).

However, there is some debate over the classification of the different species due to the fact that some have been known to interbreed, indicating that they could be sub-species instead[2]. Baboons are incredibly sociable and intelligent animals that are known to form close bonds with other members of the troop that often last for life. They are also incredibly adaptable animals but their population numbers are seriously declining throughout their natural habitat primarily due to poaching activity, predatory activity by lions, and habitat loss.

Male baboons are two times larger than females. Baboons can reach 14 to 30 inches in height at the shoulder and 50 to 100 pounds in weight[3]. The body of baboon is covered with fur that can be dark olive or yellow in colour. Males and females look alike, except that females do not have long hair around their necks. Baboons have long, dog-like muzzle and strong jaw equipped with sharp canines. Unlike primitive monkeys, baboons do not have prehensile tails that can be used as an extra limb in the treetops. Baboons are mainly terrestrial animals but can climb trees occasionally when escaping from predators. They travel large distances in the early morning and late afternoon in the search for food. Baboons will eat any type of food that is available at the moment and called opportunistic 
feeders [4]. The majority of their diet consists of fruit, seed, berries, roots, tree bark, tree sap and various insects, shellfish, fish, birds and small mammals.

Baboons live in groups called troops. They consist of 7-8 males, twice as many females and their offspring. Dominance in the troop is established through fights. There are certain hierarchies among the females in the group also. Females are in charge of accepting or rejecting newcomers (i.e. young, sexually mature males) to the group. Baboons use 30 different sounds for communication. They are able to grunt, scream and bark. Besides vocalization, baboons can yawn, smack their lips or shrug their shoulder to communicate.

Social bonds between members of the group are established through grooming. The animals spend the hottest part of the day in careful removal of ticks and other pests from the fur of other members of the group. They are territorial animals that will aggressively defend their territory and family against other baboons and predators. Main predators of baboons are large cats such as lions, hyenas, leopards, wild dogs, cheetahs, eagles, crocodiles and pythons[5]. Despite their high population numbers and adaptability, many baboons are killed each year due to conflict, poaching pressure for bush meat and to capture babies for the illegal pet trade in many countries.

Baboons can mate throughout the whole year. Pregnancy lasts for six months and ends with one baby. Mother will carry her baby close to her stomach when she is on the move. After several weeks, the baby is strong enough to start riding on the mother's back. Baboons reach sexual maturity between the age five and eight. Young males leave their native groups, while females stay. Baboons can survive up to thirty years in the wild and up to forty-five years in captivity[6].

This present study investigated the level of intellectualism and facts on the olive baboons (Papio anubis) at Yankari Game Reserve Nigeria.

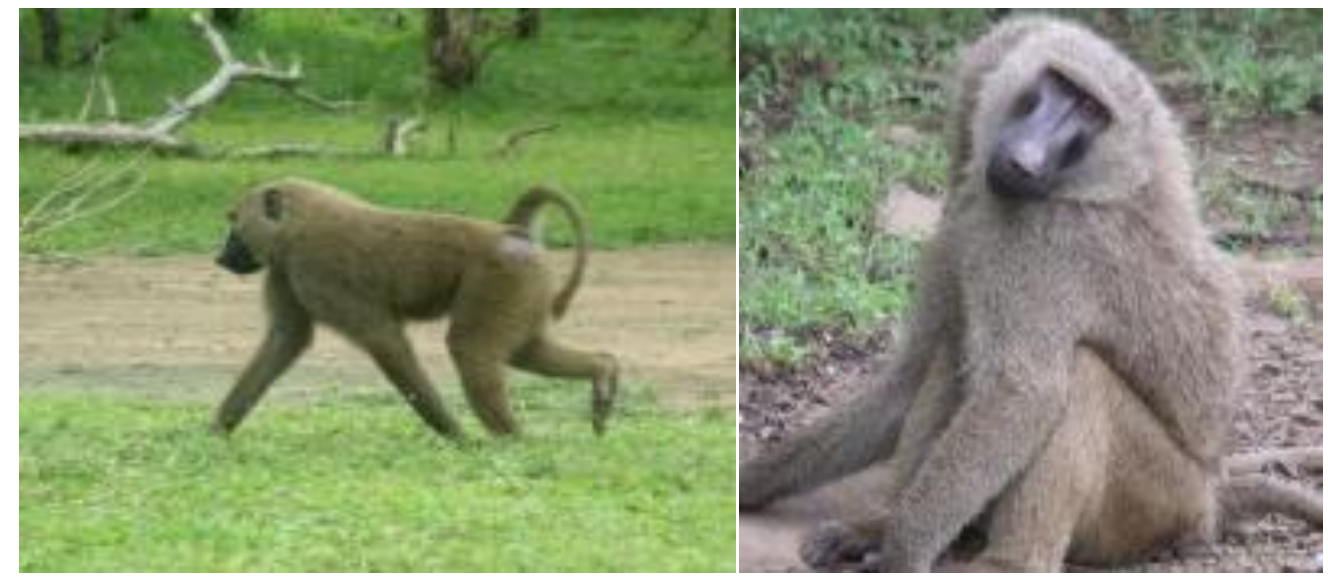

Plate i: Olive baboons at Yankari Game Reserve, Nigeria.

\section{MAterials AND MeTHOdS}

The materials used in this study were camera phones of high magnification, food items, and recording sheets. Direct observations were made on the baboons as they exhibit one behavioural characteristic or the other as well as evidence from the rangers at the YGR.

\section{RESULTS AND DISCUSSION}

\section{The Types of Food Eaten by the YGR Baboons}

The baboons are opportunistic omnivores, with an extremely diverse diet. They exploit a wide variety of foods - a real necessity in highly seasonal environments in which food availability varies in abundance throughout the year. Their diet includes berries, seeds, pods, grass, shoots, twigs, fruits, bulbs, bark, flowers, roots and also insects. But in YGR, many a time these diets were lacking so they depend on the food brought by tourists to the game reserve for their foods. It worthy to note that once the baboons sight their food anywhere in the gathering of visitors to the reserve, they pretend so as to keep the minds of the visitors away from them. With a strong agility, the baboon would approach the direction of the foods and stole them away while another baboon follows. They open windows of buses, houses, doors, and bags with their powerful hands and tore leather bags using their strong canines. Their strong limbs are highly adapted to running and escape their predators. 


\section{Behavioural Strategies to Overcome Predation}

The male species are powerful fighters and show little fear of larger animals, including humans. They are always in front of the troops slowing down in a movement sometimes to allow the younger ones move forward whenever danger is perceived. They have been known to successfully take on leopards, their worse enemies. Visual communication is important to deter both attacks from predators and fighting among male baboons, which can lead to costly injuries. Baboons have many signals to communicate a threat, including intense staring, eyelid displays, ground slapping, audible chewing, teeth grinding, yawning (to show formidable canine teeth), eyebrow-raising, ear flattening and shaking of rocks and branches[7]. Most baboons at YGR live in hierarchical troops of 5 to 15 animals which are socially based on a core of females and may include several transient males. Baboon males leave their birth group, usually before they reach sexual maturity, whereas females stay in the same group their whole life. Using vocal exchanges, baboons can determine dominance relations between individuals a scene which is popular among Yankari Baboons.

\section{Reproduction}

The baboons breed all year round and while they don't have a strict breeding season, there are peaks in mating and births at certain times of year. When a female is ready to mate, the dominant male of their sub-group will defend his right to mate with her fiercely but despite his efforts, female baboons mate with many males in the troops during their lives. After a gestation period of six months, the female Baboon gives birth to a single infant that grabs onto her fur instantly and clings onto her below. When they are born, young baboons have contrasting colours to their parents and are tolerated by the troop until they change colour, and grow their adult fur after about two months. Young females remain with their mother and the two will often form very close bonds throughout their lives, whereas males are chased out of the troop and are forced to try and prove themselves to another group.

\section{Interaction of Yankari Baboons with Humans}

Baboons in Yankari have adapted remarkably well to visiting human populations throughout the year but the fact that they often feed on crops has led to them being hunted by farmers. They are also hunted and eaten as bush meat in many parts Nigeria but it is their dwindling habitats that is causing the biggest problem for them. Vast areas of forest are cleared every day to make room for expansion in the reserve by the Bauchi State Government Nigeria or to log the tropical timbers which mean that baboons have fewer areas where they can sleep safely in the trees. The grasslands are also dwindling in size as land is turned over to livestock for grazing or used for the expansion of growing settlements. The implication is that baboons in YGR are often seen at human residential areas leading to one harassment or the other by the animals on visitors.

\section{The Immediate Dangers Facing the Yankari Baboons}

Because of their size, and the fact that they spent the majority of their lives on land, they are preyed upon by numerous predators throughout their natural habitat. Wildcats such as lions, leopards and cheetahs are the most common predators of the Yankari baboons along with some reptiles such as large pythons, as well as African wild dogs and birds of prey that hunt the smaller and more vulnerable one. Humans, however, pose the biggest threat to Yankari baboons as they are often poached and killed for meat, hides and rituals, and are even shot by farmers who consider them as pests, fearing for their crops. Their numbers though are being most affected by the loss of their once vast natural habitats, which are being subjected to deforestation for agriculture or land clearance for grazing and growing human settlements.

\section{Conservation Status of Yankari Baboons and Baboons Generally}

Today, four species of baboon are listed by the International Union for Conservation of Nature (IUCN) as a species that is of least concern(LC) from becoming extinct in the wild in the near future. The Guinea baboon is listed as a near threatened (NT) species, and this is followed by the olive baboon which is mostly domicile in the YGR. However, despite still being relatively widespread, population numbers are declining in all species due to poaching and habitat loss, with populations in certain areas of game reserve rapidly becoming more and more isolated from one another. They are found throughout many of Africa's national parks and reserves where they play a vital role in the upkeep of the eco-system. Baboons are one of the most abundant and wide-spread species of monkey 
in Africa. Baboons are close evolutionary relatives to humans according to evolution biology, and on average, baboons and humans have a genetic similarity of $94 \%$ [8].

Like many primates, baboons are highly social. They live in social groups of around twenty to fifty animals, including several adult females, adult males, and many offspring. Compared to many other monkeys, baboons are unusual in that, rather than living in trees, they spend most of their waking hours on land, ranging across African savannas. Yankari baboons can adapt to a range of habitats, and they eat a wide variety of foods, including leaves, roots, fruits, seeds, eggs, and insects. Baboons also occasionally hunt and capture rabbits, baby gazelles or small monkeys. Maybe, because of their adaptability, baboons have radiated into several morphologically and behaviourally distinct subspecies, including yellow baboons, olive baboons (which are dominant in YGR), chacma baboons, guinea baboons, and hamadryas baboons[9-18].

\section{Baboon Species and their Distribution Globally}

The distribution pattern of baboons worldwide is shown in the table below. However, a species may be found in other regions not mentioned in the table below due to seasonal migration from one location to the other by baboons prompted by climatic factors, predators, and poaching activity of humans.

Table1. Distribution of baboons in Africa and some parts of the world according to UICN data and field observation

\begin{tabular}{|c|c|c|}
\hline Species & Common name & Area found \\
\hline Papio cynocephalus & Yellow baboons & Guinea, Nigeria \\
\hline Papio cynocephalus cynocephalus & Central yellow baboon & Guinea, CAR, CAMR \\
\hline Papio cynocephalus ibeanus & Ibean baboon & Nigeria, CAMR \\
\hline Papio cynocephalus kindae & Kinda baboon & Guinea, CAR, TANZ \\
\hline Papio Anubis & Olive baboon & Nigeria, GUN,CAMR \\
\hline Papio hamadryas & Hamadryas baboon & Guinea, India, AUS \\
\hline Papio papio & Guinea baboon & Guinea, Nigeria,ARA \\
\hline Papio ursinus & Chacma baboon & India, AUS, GUN, \\
\hline Papio ursinus ursinus & Cape chacma & SA, AUS,S.S Nigeria \\
\hline Papio ursinus griseipes & Gray-footed chacma & SA, TANZ, UGAN \\
\hline Papio ursinus raucana & Ruacana chacma & SA, TANZ, AUS, GUN \\
\hline Theropithecus gelada & The gelada baboon & GUN, S.S Nigeria \\
\hline
\end{tabular}

UICN(International union for the conservation of nature), CAR(Central African Republic),CAMR(Cameroon), GUN(Guinea), ARA (Arabia) AUS(Australia), SA(South Africa), UGAN(Uganda), TANZ(Tanzania), S.S(South-south). It is possible for some species to be found in other areas not indicated in the above table. This is because, baboons are active travellers.

\section{Conclusion}

Humans kill baboons for many reasons. They can be killed because of their tendency to be viewed as agricultural pests as well as for their skins. This is very more common with the Yankari baboons. Use of baboons in laboratories and medical research has also increased. Habitat loss due to overgrazing, agricultural expansion, irrigation projects, and overall human settlement growth is a threat to baboons. The erection of new buildings in YGR Bauchi has also encouraged the loss of habitat of baboons. It is therefore warned that further expansion in buildings and athletic facilities in the Yankari game reserve may aggravate the plights of the olive baboons in this game reserve. The authority of concerned should ensure that natural habitat of the olive baboons is protected for posterity.

\section{ACKNOWLEDGEMENT}

The author is grateful to the management of Yankari Game Reserve Bauchi, Nigeria, The Federal Polytechnic Bali, and the Department of Science Laboratory Technology(SLT), as well as 2016/2017 National Diploma II (ND II) Students of SLT Department, for help offered. 
Intellectualism and Interesting Facts on Baboons (Papio anubis Les.; Family: Cercopithecidae) (the olive baboons) in Yankari Game Reserve, Bauchi, Nigeria

\section{REFERENCES}

[1] Post, D.G. (1981). Activity patterns of yellow baboons (Papio cynocephalus) in the Amboseli National Park, Kenya. Animal Behaviour; 29: 3

[2] Coelho, A.M. (1974). Socio-bioenergetics and sexual dimorphism in primates. Primates 15: $263-$ 269.

[3] Demment, M.W. (1983). Feeding ecology and the evolution of body size in baboons. Afr J. Ecol 21: 219-233.

[4] Pochron, S.T. (2000). The core dry-season diet of Yellow baboons (Papio hamadryas cynocephalus) in Ruaha National Park, Tanzania. Folia Primatol; 71: 346-349.

[5] Post, D.G. (1982). Feeding behavior of yellow baboons (Papio cynocephalus) in the Amboseli National Park, Kenya. Int Journal Primatology; 3: 403-430.

[6] Jolly, C.J. (1970). The seed eaters: a new model of hominid differentiation based on a baboon analogy. Man 5: 5-26.

[7] Elton, S. (2006). Forty years on and still going strong: the use of hominin-cercopithecoid comparisons in palaeoanthropology. J Roy Anthrop Inst; 12: 19-38.

[8] Alberts, S.C., Hollister-Smith J.A., Mututua, R.S., Sayialel, S.N., Muruthi, P.M. et al.(2005). Seasonality and long-term change in a savanna environment. In: Brockmann, D.K., Van Schaik, C.P, eds.. Seasonality in Primates. Cambridge: Cambridge University Press, 157-195.

[9] Whiten, A., Byrne, R.W., Henzi, S.P. (1987). The behavioural ecology of mountain baboons. International Journal of Primatology; 8: 37-388.

[10] Whiten, A., Byrne, R.W., Barton, R.A., Waterman, P.G., Henzi, S.P., et al. (1991). Dietary and foraging strategies of baboons. Phil Trans R Soc Lond B; 334: 187-197.

[11] Byrne, R.W., Whiten, A., Henzi, S.P., McCulloch, F.M. (1993). Nutritional constraints on mountain baboons (Papio ursinus): implications for baboon socio-ecology. Behavioural Ecology Socio-biology ;33: 233-246.

[12] Van Woerden, J.T., Van Schaik, C.P., Isler, K. (2010). Effects of seasonality on brain size evolution: evidence from strepsirrhine primates. Am Nat; 176: 758-767.

[13] Van Woerden, J.T., Williams, E.P., Van Schaik ,C.P., Isler, K. (2011). Large brains buffer energetic effects of seasonal habitats in catarrhine primates. Evolution; 66: 191-199.

[14] Navarrete, A., Van Schaik, C.P., Isler, K. (2011). Energetic and the evolution of human brain size. Nature 480: 91-94.

[15] Deblauwe, I., Janssens, G.P.J. (2008). New insights in insect prey choice by chimpanzees and gorillas in Southwest Cameroon: the role of nutritional value. Am J Phys Anthrop ;135: 42-55.

[16] Bonnefille, R. (2010). Cenozoic vegetation, climate change and hominid evolution in tropical Africa. Global Planet. Change, 72: 390-411.

[17] Ross, C.F., Washington, R.L., Eckhardt, A., Reed, D.A., Vogel, E.R., et al. (2009). Ecological consequences of scaling of chew cycle duration and daily feeding time in Primates. Journal Human Evolution; 56: 570-585.

[18] Von Koenigswald, W., Rensberger, J.M., Pfretzschner, H.U. (1987). Changes in the tooth enamel of early Paleocene mammals allowing increased diet diversity. Nature ;328: 150-152. 